\title{
OPEN
}

Published online: 04 December 2019

\section{Publisher Correction: Intrinsic activation of cell growth and differentiation in ex vivo cultured human hair follicles by a transient endogenous production of ROS}

María I. Calvo-Sánchez, Sandra Fernández-Martos, Juan José Montoya (1) \& Jesús Espada

Correction to: Scientific Reports https://doi.org/10.1038/s41598-019-39992-8, published online 14 March 2019

This Article contains errors.

In the Results and Discussion section where,

"First, we verified that treatment of resting (telogen phase) human hair follicles with low concentrations of 5 mALA, a precursor of PpIX, and subsequent irradiation with a moderate red-light dose promoted a transient ROS burst in the cultured mini-organs (Fig. 1B).”

should read:

"First, we verified that treatment of late resting (telogen)/early growing (anagen) phase human hair follicles with low concentrations of $5 \mathrm{mALA}$, a precursor of PpIX, and subsequent irradiation with a moderate red-light dose promoted a transient ROS burst in the cultured mini-organs (Fig. 1B)."

Additionally, in the Materials and Methods section under subheading 'Ex vivo culture of human hair follicles' where,

"Follicular units (FUs) in the resting (telogen) phase, typically containing one or two hair follicles and surrounding fatty and dermal tissue remnants, were dissected and selected by expert trichologists at the Ramón y Cajal Hospital Dermatology Service using standard morphological criteria."

should read:

"Follicular units (FUs) in late resting (telogen)/early growing (anagen) phase, typically containing one or two hair follicles and surrounding fatty and dermal tissue remnants, were dissected and selected by expert trichologists at the Ramón y Cajal Hospital Dermatology Service using standard morphological criteria.”

Additionally, in Figure 3A the panels have been inadvertently rotated. The correct Figure 3 appears below as Figure 1. 
A
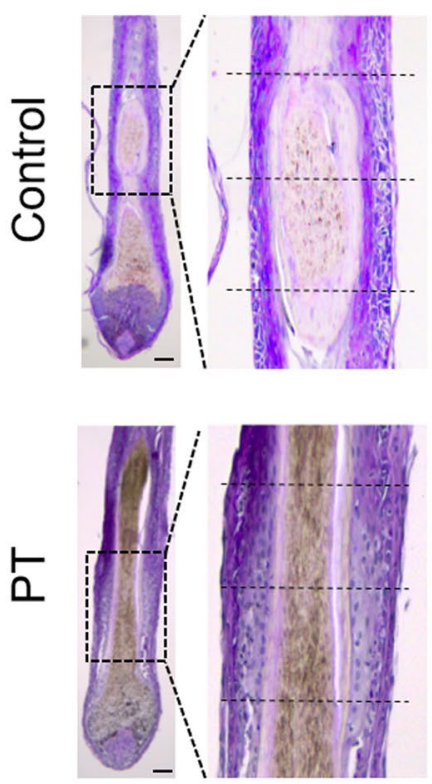

B
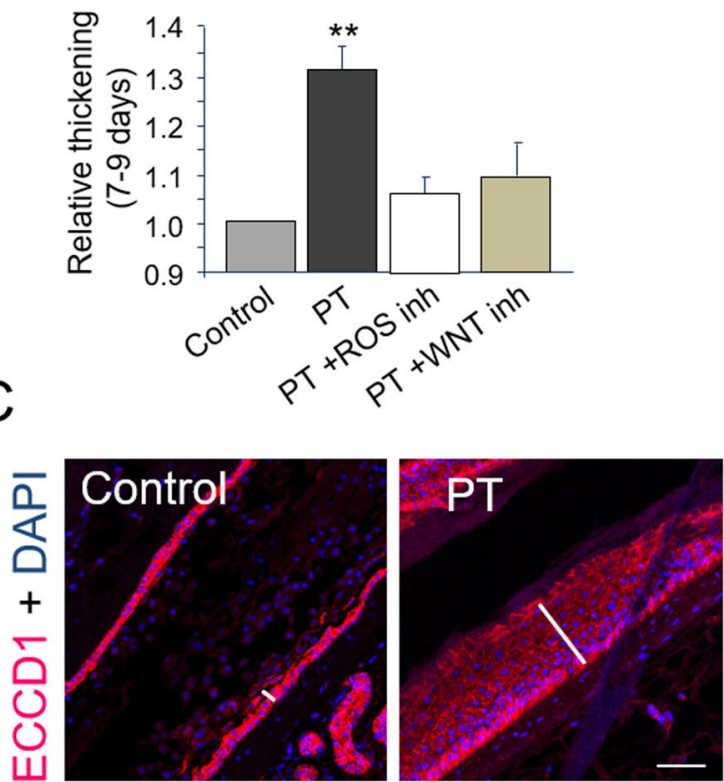

D

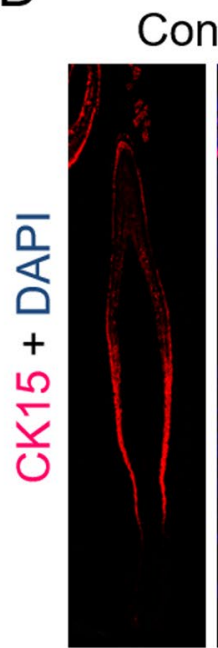

\section{trol}

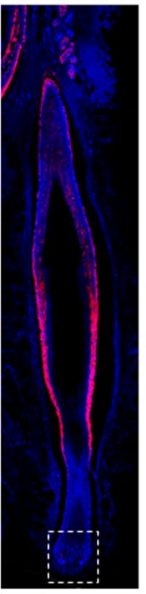

ax

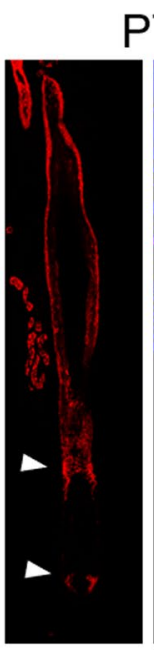

$\mathrm{PT}$
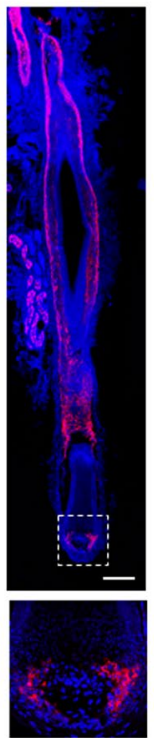

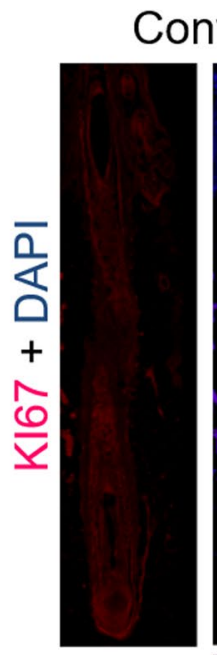

\section{trol}
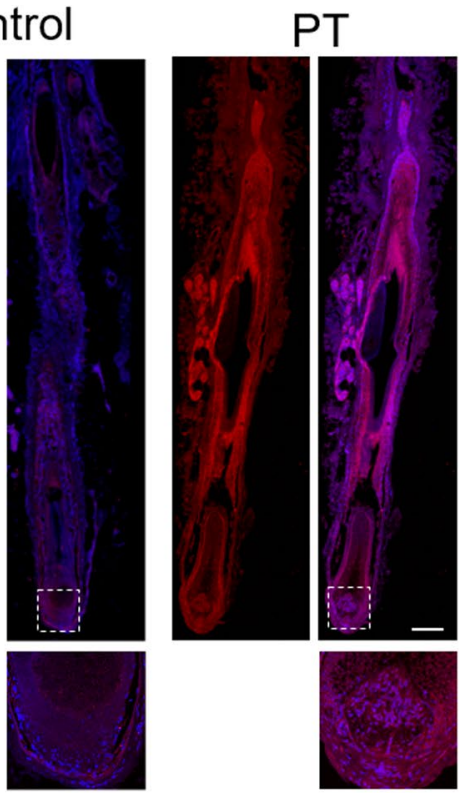

Figure 1.

(1) Open Access This article is licensed under a Creative Commons Attribution 4.0 International License, which permits use, sharing, adaptation, distribution and reproduction in any medium or format, as long as you give appropriate credit to the original author(s) and the source, provide a link to the Creative Commons license, and indicate if changes were made. The images or other third party material in this article are included in the article's Creative Commons license, unless indicated otherwise in a credit line to the material. If material is not included in the article's Creative Commons license and your intended use is not permitted by statutory regulation or exceeds the permitted use, you will need to obtain permission directly from the copyright holder. To view a copy of this license, visit http://creativecommons.org/licenses/by/4.0/.

(C) The Author(s) 2019 